TITLE:

Acidic fibroblast growth factor (FGF-1) in the anterior horn cells of ALS and control cases( Abstract_要旨)

AUTHOR(S):

Kage, Makoto

\title{
CITATION:
}

Kage, Makoto. Acidic fibroblast growth factor (FGF-1) in the anterior horn cells of ALS and control cases. 京都大学, 2002, 博士(医学)

ISSUE DATE:

2002-03-25

URL:

http://hdl.handle.net/2433/149689

RIGHT: 


\begin{tabular}{|c|c|}
\hline 名 & 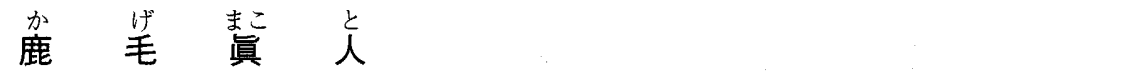 \\
\hline 学位(専攻分野) & 博士（医＼cjkstart学） \\
\hline 学位記番号 & 医 博 第 2459 号 \\
\hline 学位授与の日付 & 平 成 14 年 3 月 25 日 \\
\hline 学位授与の要件 & 学 位 規 則第 4 条第 1 項該当 \\
\hline 研究科・尃攻 & 医 学 研 究 科 脳 統 御 医 科 学 系 専 攻 \\
\hline 学位論文題目 & 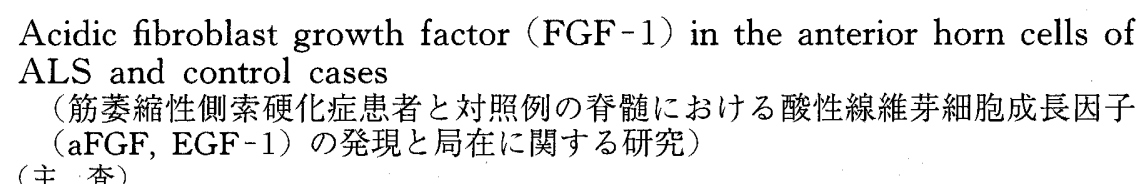 \\
\hline
\end{tabular}

\section{論文 内容の要旨}

運動ニューロンの生存・維持に関わる神経栄養因子を明らかにすることは, 運動ニューロン疾患の病態解明と治療法の開 発にとって重要である。酸性線維芽細胞成長因子 (aFGF, FGF-1) は, 中胚葉性および神経性外胚葉性由来の細胞群に対 する成長因子であるが，脳や網膜などの中枢神経系に豊富に発現していることから，神経栄養因子およびグリア増殖因子と しての作用が注目されてきた。ラット脳では，aFGFは主として皮質下のニューロンに局在している。さらに $\mathrm{aFGF} は$ はュ ーロンの生存・維持機能を有するとともに，アセチルコリン合成酵素であるコリンアセチル基転移酵素（choline acetyltransferase；ChAT）の活性を上昇させる。最近 Kerhoff H. らは，aFGFがヒト脊䯕前角のニューロンに局在してい ることを報告した。しかし運動ニューロン（コリン神経）が $\mathrm{aFGF}$ を含有している直接的な証拠はまだ得られて扔らず， ALS 患者での aFGF 陽性ニューロンの詳細な検討もなされていない。そこで本研究では，免疫二重染色法と RT-PCR 法 を用いて·ALS 患者と対照例の脊䯣における $\mathrm{aFGF}$ の発現と局在，コリン神経との関連について検討した。

対照例挍よび ALS の剖検後の脊䯣を $4 \%$ \%ルマリンで浸潤固定したのち, $20 \mu \mathrm{m}$ の薄切切片にし， 3 種類の aFGF モノ クローナル抗体（AF-152，AF-IC10, AF-114）を用いて免疫組織化学的に検討した。運動ニューロンの同定には ChAT ポリクローナル抗体（AB114-P) を用い，aFGF モノクローナル抗体と組合わせ，免疫二重染色法を行った。aFGF の発 現量は，脊髄から総 RNA を抽出し逆転写酵素を用いて $\mathrm{cDNA}$ を作成した後， $\mathrm{aFGF}$ 遺伝子を特異的に増幅するプライマ 一を用いたRT-PCR 法で検討した。

対照例では，脊髄前角のニューロンに限局して $\mathrm{aFGF}$ 蛋白を検出した。 $\mathrm{aFGF}$ 陽性ニューロンの分布は ChAT 陽性の運 動ニューロンの分布とほほ一致していた。aFGF と ChAT の免疫二重染色法の結果, ChAT 陽性の運動ニューロンの95.9 \%が aFGF 陽性であった。一方，aFGF 陽性ニューロンのうちの $98.0 \%$ が ChAT 陽性であった。ALS 例では aFGF 陽性二 ューロンの数が著減するとともに，残存ニューロンに局在する $\mathrm{aFGF}$ 免疫染色の強度も著明に低下していた。 $\mathrm{aFGF}$ 遺伝子 を RT-PCR 法で解析したところ，aFGF 陽性バンドは対照例では全例で検出されたが ALS 例の脊䯣ではほとんど検出さ れなかった。

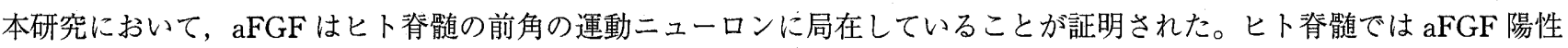
ニューロンのうちの $98.0 \%$ がコリン神経であり，aFGFがコリン神経の機能に深く関わっていることを示唆している。また ラットでは, $\mathrm{aFGF}$ は脳神経の運動核や前脳基底部のコリン神経に対し強力な栄養作用を有していることが報告されており， ヒト脊髄に扔いても $\mathrm{aFGF}$ はコリン神経の生存や機能維持に関わる栄養因子として作用している可能性がある。ALSに扔 いては，aFGF 陽性の神経細胞は著明に減少するとともに aFGF mRNA の発現が著減する。免疫組織化学の結果は，残存 する運動ニューロンにおいても $\mathrm{aFGF}$ の発現が低下していることを示唆している。しかしながら $\mathrm{aFGF}$ 発現の著明な低下 が 1 次的なものか 2 次的なものか判断することは困難である。この問題を明らかにするために家族性 ALS の原因遺伝子で あるSOD1変異遺伝子のトランスジェニックマウスを用いて研究することが今後の課題である。 


\section{論文審査の結果の要旨}

酸性線維芽細胞成長因子（aFGF, FGF-1）は中枢神経系に豊富に存在する神経栄養因子・グリア増殖因子である。ラッ トでは，aFGFは一部のニューロンによって産生され，ニューロンの生存・維持機能を有するとともに，コリンアセチル基 転移酵素（choline acetyltransferase；ChAT）の活性を上昇させる。これらの結果は，aFGF がアセチルコリン作動性神経 （コリン神経）の内因性の神経栄養因子のひとつである可能性を示唆している。しかしながら，ヒト脊䯣の運動ニューロン （コリン神経）における検討はほとんどなされていない。

そこで本研究では，免疫二重染色法とRT-PCR 法を用いて，筋萎縮性側索硬化症（ALS）患者と対照例の脊髄に扔ける $\mathrm{aFGF}$ の発現と局在，およびその運動ニューロンとの関連について検討した。

本研究の結果， $\mathrm{aFGF}$ はヒト脊髄前角の運動ニューロンに局在して㧍り，ALSに㧍いては，aFGF 陽性の神経細胞は著 明に減少するとともに, aFGF mRNAの発現が著減することが証明された。これらの結果は，aFGFがヒト運動ニューロ ンに存在する栄養因子であり, $\mathrm{aFGF}$ の発現低下が運動ニューロン疾患の病態に関わっている可能性を示唆している。

以上の研究は運動ニューロンの生存・維持に関わる神経栄養因子の解明に貢献し, 運動ニューロン疾患の病態解明と治療 法の開発に寄与するところが多い。したがって，本論文は博士（医学）の学位論文として価值あるものと認める。な损，本 学位授与申請者は，平成14年 2 月 4 日実施の論文内容とそれに関連した試問を受け，合格と認められたものである。 